\title{
Choosing and learning: Semiosis means choice
}

\author{
Kalevi Kull \\ Department of Semiotics \\ University of Tartu, \\ Jakobi 2, 51005 Tartu, Estonia \\ e-mail: kalevi.kull@ut.ee
}

\begin{abstract}
We examine the possibility of shifting the concept of choice to the centre of the semiotic theory of learning. Thus, we define sign process (meaning-making) through the concept of choice: semiosis is the process of making choices between simultaneously provided options. We define semiotic learning as leaving traces by choices, while these traces influence further choices. We term such traces of choices memory. Further modification of these traces (constraints) will be called habituation. Organic needs are homeostatic mechanisms coupled with choice-making. Needs and habits result in motivatedness. Semiosis as choice-making can be seen as a complementary description of the Peircean triadic model of semiosis; however, this can fit also the models of meaning-making worked out in other shools of semiotics. We also provide a sketch for a joint typology of semiosis and learning.
\end{abstract}

Keywords: biosemiotics; decision-making; free choice; general semiotics; homeostasis; need; non-algorithmicity; nowness; post-Darwinism; semiotic quanta; sign typology; types of learning

Der Lebensvorgang ist nicht eine Sukzession von Ursache und Wirkung, sondern eine Entscheidung. ${ }^{1}$

Viktor von Weizsäcker (1940: 126)

It would be foolish to claim that one can tackle this topic and expect to be satisfied.

Francisco Varela (1999: 266)

1 A possible translation could be: "Life is not a sequence of cause and effect, but choice". 
The aim of this study is to clarify the relationship between semiosis and learning, and also the mutual relatedness of types of semiosis and types of learning. For this purpose, we need a general model that would describe the overlapping features of learning and semiosis, including the primary forms of these processes.

The model we propose consists in a slight redefinition of the general terms of learning, memory and semiosis. We define these terms bringing in the concept of free choice, which has been downplayed by both the computational and the neoDarwinian approaches to learning. We observe that, in semiotics, the concept of free choice has not received the attention it deserves.

In the computational approach, learning is commonly modelled as an effect in certain networks of logic gates (formal neural networks). Since the work of logic gates is algorithmically deterministic it implies that free choice, which assumes an absence of algorithm at some moments of behaviour, would require a model capable of describing free choice as a non-algorithmic event. (We find the latter possible via the introduction of the dimension of nowness.)

In neo-Darwinian general biology, which explains the features of organisms on the basis of natural selection, the causal (to some extent free and creative) role of organism has not been in focus. As Randolf Menzel (2003: 59) describes this, "the basic concept of modern biology is that the relationship between phylogenetic and individual memory is a one-way road from the phylogenetic to the individual memory and not vice-versa". This does not mean that the neo-Darwinian framework completely denies organisms' choices; it simply derives the choices from natural selection, natural selection is seen as responsible for choices made by organisms (as, for instance, in Okasha 2018); instead of studying the phenomenon of choice itself, attention moved to the predictability of decision-making (Glimcher 2002) ${ }^{2}$; some neo-Darwinian accounts derive even human decision-making from evolutionary fitness (e.g., Kenrick et al. 2009).

Contrariwise, an approach that has sometimes been called the post-Darwinian paradigm, emphasizes the fundamental role of organisms as agents and turns attention to the choices organisms make (Noble, Noble 2018). According to postDarwinian theory, organisms' choices can make evolution directional. Instead of stating that "learning is evolutionarily prepared" 3 , it would state that evolution is prepared by learning. "Diving deeper into the early forms of adaptive behavior", Menzel (2003: 60) adds, we can see that "unicellular organisms like bacteria [...],

2 Predictability of decisions is also the main interest in economic analysis of (human) consumer choice - which is one of most active areas of choice research today (see, for instance, Hess, Daly 2014).

3 This clearly neo-Darwinian statement comes from Peter Hammerstein and Jeffrey R. Stevens (2012: 7). 
algae and ciliates adapt their metabolic machinery and, in the case of ciliates, their motor behavior, to changing environmental demands and pass such adaptations to successive generations via cytoplasm transmission when their cell bodies divide". Choice can be a source of evolutionary innovation.

The roots of the post-Darwinian paradigm go back at least to the concept of organic selection, which is opposed to natural selection, as defined by James Mark Baldwin. Namely, organic selection can be interpreted as pointing out the role of organisms' free choice. Conwy Lloyd Morgan (1896) had similar ideas. ${ }^{4}$ Charles Sanders Peirce, when writing on agapastic evolution, ascribed creativity to organisms. Later, Jean Piaget emphasized the role of organisms' choices (see also Scarfe 2018). Lynn Margulis states similarly: "[O]rganisms choose" (Margulis, Sagan 1995: 222). Also, for instance, Ben Williams (1994: 84) writes:

As argued by Herrnstein (1970), all behavior is choice, in the sense that there are always alternatives other than the response measured by the experimenter. Thus, the animal is always "deciding" which response to perform.

Thus the idea that organisms make choices is not new. John Zachary Young (1987: 148) mentions: "The realization that choice is a property of all living things gives us great help in understanding the world and our place in it". The idea that theories of choice and of learning can be jointly approached on the basis of semiotics, has also been suggested earlier (Stables, Gough 2006). What has not been so often formulated, however, is the identification of choice-making with semiosis. With this, we develop here our earlier work on the role of choice in semiosis (Kull 2015b, 2017, 2018).

\section{The sketch of the basic model}

By 'semiosis' we mean the process of choice-making between simultaneously alternative options.

We define 'semiotic learning' as the leaving behind of such traces by choices, which could influence further choices. These traces of choices will be called 'memory'. Further modification of traces from learning will be called 'habituation'.

Organisms' needs stem from mechanisms of homeostasis which are coupled with the capacity of making choices. Needs and habits are the sources of motivatedness.

4 He also provides a criterion for choice: "an alteration or modification of response in the light of individual experience” (Morgan 1896: 265). 


\section{Comments on the basic model}

These definitions may need some comments, since they are very brief and very general and do not explicitly follow the classic definitions in semiotics or related areas in biology, psychology or education research.

\subsection{Semiosis as choosing}

Semiosis is the process in which the sign (and meaning) emerges. In other terms, semiosis is interpretation, the formation of interpretant - according to Peirce. Yet it is important to emphasize that interpretation always includes choice (as also noted by Umberto Eco; e.g., in Eco 2018: 346-347). Processes without choice would be algorithmic transformations, or simply codes. In this sense, codes are both products and preconditions of semiosis, not semiosis itself. Meaning exists only within interpretation processes.

Thus we describe semiosis as decision-making in an ambiguous situation. We see this as a complementary description of the Peircean triadic model of semiosis. The aspects in the choice process that correspond to the three relata can be described as follows. Representamen by itself is ambiguous, as it is possible to interpret it in various ways. This means that representamen may refer to different objects. In semiosis, a choice is made between these possibilities, which appear as options, and representamen becomes related to a particular object. This relation is a decision, which is the same as interpretant. Representamen, object and interpretant emerge together at the event of choice-making. In this stands the irreducibility of the triad, which Peirce described.

According to this description, semiosis supposes a choice between options. A peculiarity of semiosis consists in its momentariness and presentness. Because optionality requires the simultaneous presence (co-presence) of possibilities, the existence of choice implies the existence of finite present, the nowness. Accordingly, semiosis, while being a process for an external observer, is what happens within one subjective moment of the agent. This is also why semiotics is incompatible with a physicalist concept of time, and with physicalism altogether - "there is no present or nowness in fundamental physical theories" (Franck, Atmanspacher 2009: 212). Since the finite present is a fundamental and universal feature of subjectivity, it follows that free choice, semiosis, and subjectivity are coextensive. The present moment is the quantum of semiosis. Semiosis stops time - in the sense that the Now emerges in semiosis. Semiosis is choice-making.

Thus the definition of semiosis through choice can be seen as equivalent to the definition of semiosis as an irreducible triadic relation in the Peircean tradition. In case of elementary semiosis, representamen, object and interpretant are not 
temporally separated. This is precisely why semiotics is a study of the mind - since mind assumes nowness. Moreover, with a focus on time, biosemiotics can bridge the inside and outside perspectives. Franck and Atmanspacher (2009: 212) write:

As an alternative to dual-aspect or dual-perspective [first-person and thirdperson] accounts, it has occasionally been proposed to translate the mind-matter distinction into terms of time [...]: mental presence is addressed in terms of mental time while material reality is addressed by physical time. We consider this proposal as particularly promising because time plays a substantial role in both the mental and the material domain, yet this role shows characteristic differences in the two domains.

The possibilities (options) to be chosen in semiosis are themselves habits (or codes) that appear as occasionally incompatible (or in conflict) - they are alternatives. These habits bring the past to the present and work as anticipations.

\subsection{An example of semiosis: Visual-saccadic decision-making}

As an example of semiosis, we suggest here a semiotic interpretation of visualsaccadic decision-making (for a physiological description of this process, see, e.g., Glimcher 2001; analogical examples are provided in Cheville 2008).

For an organism with movable eyes, if there is enough light, the visual field provides a simultaneously existing patterned diversity. It consists of potential loci to focus on. A functional system that includes light receptors, neural cells and muscles, makes an involuntary decision and turns the eye - it makes a quick saccadic movement. With this decision as interpretant, the choice is made between many options of potential focus. Thus, a visual field pattern as representamen is interpreted and an image element as object is created. What is important in our context is that (a) the choice can be involuntary and unconscious, and (b) the choice of sight takes place within one subjective moment in which the possibilities are simultaneous.

According to the description of the dual premotor systems model of animal choice-making by Goldberg (1992), we can identify the conflicting options as premotor systems. In a more general case, there can be many options, two characterizing just a minimal system.

\subsection{Semiotic learning}

The interpretant is a decision in the momentary event of choice-making. If the decision leaves some traces which could influence further choices (in an analogical situation), then this is what we call learning, and this corresponds well to what is commonly called learning. 
Making a particular decision means relating - making a relation, making a particular representamen-object connection. This is a connection that is made. Madeness is characteristic of all sign-relations. Sign-relations are made in the sense that learning is making a new connection between something that would probably not be connected by spontaneous physico-chemical processes, and which solves the situation of incompatibility or confusion, the situation of indeterminacy due to optionality.

Learning is the process of building and of modifying memory. Learning is of several types, depending on the type of connections made. We describe the types of semiotic learning in Section 3 below.

Semiotic learning is different from algorithmic learning. ${ }^{5}$ Semiotic learning can be defined as establishing a sign relation (or code) in result of choices. Algorithmic learning may establish codes without choice, without semiosis.

Thus computational and semiotic descriptions of learning diverge. The computational learning (or algorithmic, or formal learning) can be defined as based on a complex of logic gates that change or modify a classification using certain criteria. According to the computational approach, the selection of behavioural paths is described via sequential operations, such as IF $x$ THEN $y$ ELSE $z$. Here, neither $y$ and $z$, nor $x$ and non- $x$, are true options, for they can be handled sequentially and thus cannot build behavioural indeterminacy. By behavioural indeterminacy we mean the "don't-know-what-to-do" situation provided by multiple options, by incompatibility of algorithms or conflicting instructions that are simultaneously applicable and requiring making choices.

The semiotic concept of learning describes learning as a process that starts with behavioural indeterminacy (describable also as a situation of incompatibility, confusion, logical conflict, problem-situation, ambiguity). This is a situation in which there are options to choose from. Options require simultaneity. Only the possibilities that are inseparable in time can be seen as options for a living system. Optionality requires nowness, the specious present (Varela 1999; Kull 2015a). The situation of incompatibility is to be solved via choice. ${ }^{6}$ After making a choice, it may be followed by habituation. For semiotic learning additional criteria are not required, as the conflict itself is its cause. Thus, the semiotic concept is more general than the computational concept.

\footnotetext{
5 On semiotic learning, see also Olteanu 2018 and other contributors in Stables et al. 2018.

6 We see the operation of choice as the simplest operation that is logical and not causal (in the sense of causa efficiens) - simpler than negation, and, accordingly, prelinguistic and prehuman.
} 
Semiotic learning or establishing a new sign relation is possible only due to the specious or phenomenal present and optionality. Once the relation is established, then the habituated relation (also a code) can work without the phenomenal present, in lack of options, i.e., computationally. The latter also occurs where a semiotic relation can occur without life (e.g., in artefacts).

\subsection{Memory, memorizing}

What allows a decision being similarly repeated is the traces of the earlier decisions, which can be described either as connections established and further used in a similar situation, or as a set of constraints that canalizes and restricts future choices.

The established connections or constraints (thus, memory) are, primarily, of two types:

(A) non-restorable connections; these can serve as temporary memory;

(B) restorable or reproducible connections; these are the basis for lasting memory.

Restorability requires the existence of a mechanism that copies the connection so that it can persist despite local destruction of the connection. Restorable connection, therefore, means inheritance, and this can be of several types, including (a) restorability based on rereading a fixed pattern, such as a site of DNA or RNA, and (b) restorability based on a separate homeostatic cycle.

Note that according to this definition of memory, the location of memory can be distributed. Memory is not limited to the body of an organism. Traces in the surrounding, constructed niche, can be a part of memory.

\subsection{Motivatedness and predictability}

That the decisions can be predictable to a certain extent is an obvious consequence of memory and habituation. Predictability of decision does not contradict with the existence of free choice.

Choice or decision can always be motivated to some extent. However, in order for someone to have a choice, some freedom of choosing has to be assumed. Therefore, free choice and motivatedness do not exclude each other; rather, they are aspects of the same phenomenon.

An obvious reason for mistakenly contrasting predictability and choice is the common assumption that cause and effect are to be always separated in (nonrelativistic) physical, i.e, sequential, time. However, in case of accepting the reality 
of subjective present, the cause and effect can occur non-sequentially. The latter is a form of semiotic causation (Hoffmeyer 2007). ${ }^{7}$

Anticipation, according to our model, is nothing else than motivatedness or preference, based on the constraints established or modified in learning. Thus, affordance is also a result of earlier traces of choices that reappear during the recognition event.

\subsection{Habit, homeostasis, and semiosis}

Habituation is generally a fine-tuning of the connection made by learning. This occurs in repeated use of the same, or nearly the same, sign or choice-making. It means that when choosing, the same connection is found as in some earlier choices, thus the choice does not make a new connection, but it repeats already existing ones, still possibly deepening traces or slightly shifting constraints. Repeated decision usually strengthens the connection and causes further choices in an analogical situation to be more automatic. However, on certain occasions, if the difference is greater, a habit may reverse, and sensitization takes place.

The development of habit towards the automatization of a particular behavioural act may lead to the complete disappearance of the habit's connection to choice. In the latter case, relearning is not possible any more. Habit has turned into a mechanical code.

Habit is also a basis for motivatedness, as was explained in Section 2.5 above. But motivatedness may result not only from habit, but also from the needs of the organism. The concept of need is a difficult one for biology, and seldom used as a defined term in models of organisms, even though the importance of needs as behavioural drives is evident. The concept of choice may be helpful in defining need.

We can observe that basic needs (e.g., for nutrients, sources of energy, warmth, etc.) are related to homeostatic mechanisms. Homeostatic mechanisms are usually described as mechanical feedback cycles, without a notable difference between living and non-living systems. Thus, the way which enables the maintenance of homeostasis is seen as deterministic. However, the point is that in more complex systems (with multiple receptors and ways of action) the search for establishing homeostasis may include choice, as far as it can face optionality. The functional

7 "[...] semiotic controls may be distinguished from ordinary deterministic control mechanisms through an inbuilt anticipatory capacity based on a distinct kind of causation that I call here "semiotic causation" to denote the bringing about of changes under the guidance of interpretation in a local context" (Hoffmeyer 2007: 149; my emphasis, K. K.). 
circle, as assumed by Uexküll, includes options. Thus, we can define an organic need as homeostasis with choice, which is semiosis. In this manner, both habit with choice and homeostasis with choice are cases of semiosis.

For instance, breathing is a part of the homeostatic mechanism that keeps the partial pressures of oxygen and carbon dioxide in blood close to constant. It works almost automatically as a habit. Nevertheless, at least in critical situations there is choice at work - for instance, when choosing whether to increase the frequency of breathing or to move to another place of better air. This means there is still some possibility for learning to breath differently. As Samuel Butler noticed in his book Life and Habit, "a child breathes automatically, because it has learnt to breathe little by little" (Butler 1878: 243).

\subsection{Adjustment}

Adaptation-like transformations include processes of a very diverse nature. Besides evolutionary adaptation by natural selection, we mentioned two kinds of learning - semiotic and computational. There can also be adjustment without learning. This is a transformation due to various self-organization processes and feedback mechanisms. It includes elastic and plastic deformations of materials, in the sense of the terms as used in physics. Adjustment is what is going on in ordinary work of negative feedback cycles that are not coupled with choice-making. Adjustment may remove deviations without any choice-including measurement (measurement understood as an epistemic, i.e. semiotic, process).

What is called plastic change in contemporary biology (West-Eberhard 2003) is most often (but not always) this kind of adjustment. Plastic changes of organisms can occur both without semiotic learning or with semiotic learning involved.

\section{A joint typology of semiosis and learning}

In contemporary semiotics, the most frequently used typology of semiosis follows a simplified version of Peirce's typology of signs. Nevertheless, the identification of particular types of signs in concrete model situations often causes unresolvable debates, because the necessary and sufficient conditions in this typology are usually not explicitly formulated. Connecting the types of semiosis with types of learning could (at least to some extent) solve this ambiguity.

The typologies of forms of learning, however, are even more diverse. There are many types distinguished and several classifications provided. Bruce Moore (Moore 2004) lists nearly one hundred forms of learning (see also Kull 2018). 
The following typology of learning (from Holley 2017: 811) is used rather widely:

(a) nonassociative learning is a behavioural change brought on by repeated presentation of one stimulus with no associated stimulus or event (such as reward or punishment); [one form of it is]

- habituation;

(b) associative learning (learning by association); [this includes four classes:]

- imprinting,

- conditioning,

- imitation,

- instruction.

We follow here this typology and its terminology.

We assume that a choice that leaves some trace is always (some type of) associative learning. If traces (i.e., memory) strongly constrain or canalize behaviour in certain situations, then the behaviour is called 'habit'. Thus, habit can be modified by repetition, without new connections made along with the choice. It is in this sense that habituation is non-associative. Moreover, the canalization may be so strong that the behaviour will lose its phase of choice-making and turn into an algorithm-based behaviour.

The typology we are going to sketch is based on the relative complexity of choice made in semiosis within one moment. Choice means picking an option. The complexity of different options may vary. If a choice leaves traces, then it becomes memorized, thus learnt. Since each choice is a movement, the traces it leaves are constraints for movement. The complexity of a choice is correlated with the complexity of traces it leaves. Therefore, memory can direct the making of a particular type of choice.

The fourfold typology of choice-making that roughly corresponds to the types of learning (imprinting, conditioning, imitation, instruction) as above, is the following.

(1) Picking a "point" as one of options. This is imprinting. It is the simplest form of choice, since it does not assume any additional reasoning during the making of the choice. What is chosen turns itself to be the object. This is an iconic relation.

(2) Picking two "points" that are co-present. This is association in a narrow sense. This includes a first, and a second that is different from the first (close to the first, co-present or co-located), and takes the two as one, thus introducing 
a relation between them. The correlatedness between the two becomes interpreted as an indexical sign. Worked out by conditioning, it represents an existing correlation. (See examples in Hawkins, Byrne 2015; on the aspect of co-localization, in Stjernfelt 2014: 67-68.)

(3) Picking a track between some "points" that are co-present. In addition to (2), it includes picking the movements from one to another. This is imitation. Tracking appears as the modelling of a form. The corresponding sign is emon (Kull 2018: 140-141).

(4) Picking that is made on the basis of the form recognized, the form that is made as different. This is instruction or making an independent other. This corresponds to symbolic relation. Indeed, symbolic operations assume the capacity for the construction of the opposite, the non-existent, the negation. This is a detached, un-grounded ${ }^{8}$ relationship.

These four types of choices, related to learning and the types of sign, can be seen as the major types of semiotic quanta. They are ordered in a row of growing complexity. A higher type includes all the lower ones. We could call them semiotic quanta because they are wholes, appearing in the subjective present, in one moment. Thus the lower types of semiosis are embedded in the higher type not sequentially but in the same subjective moment. The moment itself may have a longer duration in a more complex sign. The duration of nowness is obviously related to the freedom of choice, since in the case of a shorter duration of nowness both the number of options and the complexity of operations tend to be smaller.

\section{Concluding remarks}

By considering choice as the central condition of semiotic models, we arrive at a very rich deductive repertoire for the derivation of a general semiotic theory. The assumption that semiosis requires choice justifies the established definition of the sign and clarifies the ontological difference between physical and semiotic models. It helps to understand the conditions for the emergence of subjectivity.

Free choice is simpler than often assumed. Choice means picking an option in a situation of a plurality of options. Motivatedness, preference, strategy of decision all these are not necessary for making a choice, while they all assume the existence

8 On symbols as un-grounded signs, see, for instance, Rączaszek-Leonardi, Joanna; Deacon, Terrence 2018. The symbol un-grounding problem in language acquisition. In: Deacon, Terrence; Hendlin, Yogi (eds.), Eighteenth Annual Biosemiotics Gathering Abstract Booklet. Berkeley: University of California, Berkeley. See also Cangelosi 2005. 
of choosing. The simplicity of optionality implies that the existence of choice in organisms without a nervous system is feasible.

Thus, on the one hand, choice-making can be very simple. On the other hand, however, as a necessary condition for semiosis, it both strengthens and specifies the difference from computational processes of information. It also implies that semiosis cannot be found in any single receptor or a single process, because optionality means multiplicity. Semiosis and choice are collective phenomena, in the sense that they require a collective of habits.

In addition, it may occur that if free choice is understood as the fundamental feature of sign processes, then it allows for the unification of the major semiotic models. As regards the Saussurean model, choice is the basis of arbitrariness. For the Greimasian model, choice is described by the axes of contrariness and contradiction, which represent options. According to Lotman's model, the relationship of untranslatability is the situation of choice. In view of the Uexküllian model, choice is the decision of an action in umwelt. According to the Peircean model, interpretation includes choice as we have described above. An integrated semiotic theory is feasible. ${ }^{9}$

\section{References}

Butler, Samuel 1878. Life and Habit. London: Trübner \& Co.

Cangelosi, Angelo 2005. Approaches to grounding symbols in perceptual and sensorimotor categories. In: Cohen, Henri; Lefebvre, Claire (eds), Handbook of Categorization in Cognitive Science. Amsterdam: Elsevier, 719-737.

Cheville, Julie 2008. Analytic dilemmas in real and virtual contexts: A turn to spatial semiosis. In: Flood, James; Heath, Shirley Brice; Lapp, Diane (eds.), Handbook of Research on Teaching Literacy Through the Communicative and Visual Arts. Vol. 2. New York: Routledge, Taylor \& Francis, 161-167.

Eco, Umberto 2018. Giorgio Prodi and the lower threshold of semiotics. Sign Systems Studies 46(2/3): 343-351.

Franck, Georg; Atmanspacher, Harald 2009. A proposed relation between intensity of presence and duration of nowness. In: Atmanspacher, Harald; Primas, Hans (eds.), Recasting Reality: Wolfgang Pauli's Philosophical Ideas and Contemporary Science. Berlin: Springer, 211-225.

Glimcher, Paul W. 2001. Making choices: The neurophysiology of visual-saccadic decision making. Trends in Neurosciences 24(11): 654-659.

9 Acknowledgements. I thank Claus Emmeche, Donald Favareau, Paul Cobley, Søren Brier and Luis Bruni for our impromptu 25 November 2018 seminar in Copenhagen, and many other good colleagues for helpful comments and remarks. I also thank Alin Olteanu and Andrew Stables, the guest editors of the current volume, for advice and inspiration. 
- 2002. Decisions, decisions, decisions: Choosing a biological science of choice. Neuron 36(2): 323-332.

Goldberg, Gary 1992. Premotor systems, attention to action and behavioural choice. In: Kien, Jenny; McCrohan, Catherine R.; Winlow, William (eds.), Neurobiology of Motor Programme Selection: New Approaches to the Study of Behavioural Choice. Oxford: Pergamon Press, 225-248.

Hammerstein, Peter; Stevens, Jeffrey R. 2012. Six reasons for invoking evolution in decision theory. In: Hammerstein, Peter; Stevens, Jeffrey R. (eds.), Evolution and the Mechanisms of Decision-Making. (Strüngmann Forum Reports.) Cambridge: MIT Press, 1-17.

Hawkins, Robert D.; Byrne, John H. 2015. Associative learning in invertebrates. Cold Spring Harbor Perspectives in Biology 7(5): a021709 (1-17).

Herrnstein, Richard J. 1970. On the law of effect. Journal of the Experimental Analysis of Behavior 13(2): 243-266.

Hess, Stephane; Daly, Andrew (eds.) 2014. Handbook of Choice Modelling. Cheltenham: Edward Elgar.

Hoffmeyer, Jesper 2007. Semiotic scaffolding of living systems. In: Barbieri, Marcello (ed.), Introduction to Biosemiotics: The New Biological Synthesis. Berlin: Springer, 149-166.

Holley, Dennis 2017. General Biology II: Organisms and Ecology. Indianapolis: Dog Ear Publishing.

Kenrick, Douglas T.; Griskevicius, Vladas; Sundie, Jill M.; Li, Norman P.; Li, Yexin Jessica; Neuberg, Steven L. 2009. Deep rationality: The evolutionary economics of decision making. Social Cognition 27(5): 764-785.

Kull, Kalevi 2015a. Semiosis stems from logical incompatibility in organic nature: Why biophysics does not see meaning, while biosemiotics does. Progress in Biophysics and Molecular Biology 119(3): 616-621.

- 2015b. Evolution, choice, and scaffolding: Semiosis is changing its own building. Biosemiotics 8(2): 223-234.

- 2017. What is the possibility? In: Kull, Kalevi; Cobley, Paul (eds.), Biosemiotics in the community: Essays in honour of Donald Favareau. Tartu: University of Tartu Press, 15-25.

- 2018. On the logic of animal umwelten: The animal subjective present and zoosemiotics of choice and learning. In: Marrone, Gianfranco; Mangano, Dario (eds.), Semiotics of Animals in Culture: Zoosemiotics 2.0. (Biosemiotics 17.) Cham: Springer, 135-148.

Margulis, Lynn; Sagan, Dorion 1995. What is Life. Berkeley: University of California Press.

Menzel, Randolf 2003. Creating presence by bridging between the past and the future: The role of learning and memory for the organization of life. In: Kühn, Reimer; Menzel, Randolf; Menzel, Wolfram; Ratsch, Ulrich; Richter, Michael M.; Stamatescu, Ion-Olimpiu (eds.), Adaptivity and Learning: An Interdisciplinary Debate. Berlin: Springer, 59-70.

Moore, Bruce R. 2004. The evolution of learning. Biological Reviews of the Cambridge Philosophical Society 79(2): 301-335.

Morgan, Conwy Lloyd 1896. Habit and Instinct. London: Edward Arnold.

Noble, Raymond; Noble, Denis 2018. Harnessing stochasticity: How do organisms make choices? Chaos 28: 106309.

Okasha, Samir 2018. Agents and Goals in Evolution. Oxford: Oxford University Press.

Olteanu, Alin 2018. Ecology, love and learning. In: Stables, Andrew; Nöth, Winfried; Olteanu, Alin; Pesce, Sébastien; Pikkarainen, Eetu, Semiotic Theory of Learning: New Perspectives in the Philosophy of Education. London: Routledge, 117-130. 
Scarfe, Adam C. (ed.) 2018. Nature Alive: Essays on the Emergence and Evolution of Living Agents. Newcastle upon Tyne: Cambridge Scholars Publishers.

Stables, Andrew; Gough, Stephen 2006. Towards a semiotic theory of choice and of learning. Educational Theory 56(3): 271-285.

Stables, Andrew; Nöth, Winfried; Olteanu, Alin; Pesce, Sébastien; Pikkarainen, Eetu 2018.

Semiotic Theory of Learning: New Perspectives in the Philosophy of Education. London: Routledge.

Stjernfelt, Frederik 2014. Natural Propositions: The Actuality of Peirce's Doctrine of Dicisigns. Boston: Docent Press.

Varela, Francisco J. 1999. The specious present: A neurophenomenology of time consciousness.

In: Petitot, Jean; Varela, Francisco J.; Pachoud, Bernard; Roy, Jean-Michel (eds.), Naturalizing Phenomenology: Issues in Contemporary Phenomenology and Cognitive Science. Stanford: Stanford University Press, 266-314.

Weizsäcker, Viktor von 1940. Der Gestaltkreis: Theorie der Einheit von Wahrnehmen und Bewegen. Leipzig: Georg Thieme Verlag.

West-Eberhard, Mary Jane 2003. Developmental Plasticity and Evolution. Oxford: Oxford University Press.

Williams, Ben A. 1994. Reinforcement and choice. In: Mackintosh, Nicholas John (ed.), Animal Learning and Cognition. San Diego: Academic Press, 81-108.

Young, John Zachary 1987. Choice, biological. In: Gregory, Richard L. (ed.), The Oxford Companion to the Mind. Oxford: Oxford University Press, 147-148.

\section{Свободный выбор и обучение: семиозис как процесс выбора}

В статье рассматривается возможность смещения концепции выбора в центр семиотической теории обучения. Знаковый процесс (смыслообразование) представлен через концепцию свободного выбора: семиозис определяется как процесс выбора между одновременно предоставленными альтернативами, а семиотическое обучение - как оставление выбором следов, слагающихся в память и влияющих на следующие выборы. Последующая модификация этих следов (или ограничений) называется привыканием. Органические потребности - это гомеостатические механизмы в сочетании с выбором. Потребности и привычки приводят к мотивациям и мотивированности выбора. Семиозис как выбор может рассматриваться как дополнительное описание триадической модели семиозиса, предложенной Пирсом, однако может соответствовать и моделям знакового процесса, разработанным в других школах семиотики. В статье предлагается проект совместной типологии семиозиса и обучения.

\section{Vaba valik ja õppimine: semioos on valikuprotsess}

Vaatleme võimalust nihutada valiku mõiste semiootilise õppimisteooria keskmesse. Niisiis, määratleme märgiprotsessi (ehk tähendusloomet) vaba valiku mehhanismi kaudu, Nimetame semioosiks valiku tegemise protsessi, milles valitavad võimalused on antud üheaegsetena olevikumomendis. Semiootiliseks õppimiseks nimetame valiku poolt jäetavaid jälgi, mis mõjustavad järgnevaid valikuid. Need jäljed moodustavad mälu. Nende jälgede (ehk 
piirangute) edaspidine teisendamine on harjumine. Orgaanilised vajadused on homöostaatilised mehhanismid koos nendega seotud valimisprotsessidega. Vajadustest ja harjumustest tuleneb tehtavate valikute motiveeritus. Semioosi kirjeldamist valikuprotsessina võib pidada komplementaarseks Peirce'i triaadse semioosimudeliga, kuid meie kirjelduse kaudu on seda lihtsam seostada teiste semiootikakoolkondade poolt arendatud märgiloome mudelitega. Esitame ka õppimist ja semioosi seostava tüpoloogia. 